\title{
TeChNological Assurance of Surface Roughness in PoCKet Milling
}

\author{
Jyothi Prasad Gandreddi, Eriks Gerins, Artis Kromanis \& Janis Lungevics
}
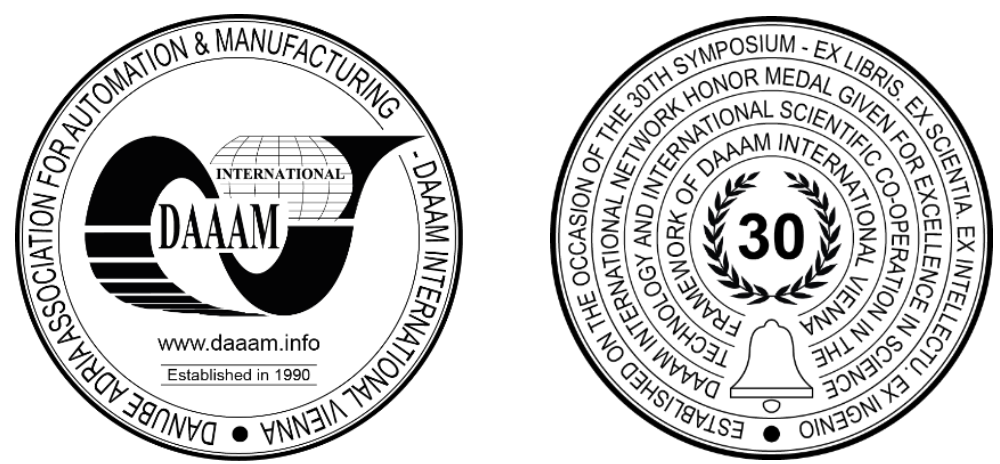

This Publication has to be referred as: Gandreddi, J[yothi] P[rasad]; Gerins, E[riks]; Kromanis, A[rtis] \& Lungevics, J[anis] (2020). Technological Assurance of Surface Roughness in Pocket Milling, Proceedings of the 31st DAAAM International Symposium, pp.0584-0591, B. Katalinic (Ed.), Published by DAAAM International, ISBN 978-3-90273429-7, ISSN 1726-9679, Vienna, Austria

DOI: $10.2507 / 31$ st.daaam.proceedings.080

\begin{abstract}
In the $21^{\text {st }}$ century milling is the main machining process to obtain complex shapes. Obtaining a smooth surface after machining is very important. The toolpaths and cutting parameters are very important to obtain good surface roughness and productivity in milling, as well as the cutting speed and feed rate are the main parameters to look out for. In the following research paper, a machining of medium carbide steels like C45 was performed to study the influence of machining parameters on surface roughness. Pocket milling of C45 steel in three toolpaths one-way, two-way, helical (inward) with $8 \mathrm{~mm}$ carbide tool at different feed rates and cutting speeds but with constant depth of cut (1 mm) for all samples is conducted to compare the surface roughness. One way tool path provided better results at low feed rate $(0.01$ to $0.03 \mathrm{~mm} /$ tooth) and at low cutting speeds $(100-250 \mathrm{~m} / \mathrm{min}$ ) but rubbing of cutting tool is more at the starting point of machining and it also results in more air gaps between two cutting paths. Due to big air gaps this toolpath may not be suitable for mass production. In two way and helical toolpaths, finer surface roughness was obtained at low feed rates. So, low feed rates are very effective in pocket milling to obtain good surface roughness. Further research may be done by varying depth of cut and further increasing cutting speeds.
\end{abstract}

Keywords: Surface roughness; Pocket milling; Feed; Cutting speed; Depth of cut

\section{Introduction}

In this modern world, among the machining tools CNC milling machines are widely used in all industries. Various CAD/CAM softwares were used to generate coding for machining in CNC machines[1]. These machines are capable of making more complex shapes and also used for mass production. Even though CNC milling is an advanced technology, many industries are facing problems in obtaining good surface quality due to lack of adaptive technologies. Obtaining a better and smooth surface is a very challenging task for every manufacturer. Milling can be done for making pockets, slots, finishing, facing, and more except cylindrical shapes by using different toolpath strategies. Choosing the right tool path strategy in the process of milling will reduce machining time, improve the surface quality of the work piece, increase tool life, increase production capability, and reduce costs and cutting forces [2]. 
Not only toolpath strategies, but also machining parameters like cutting speed, depth of cut and feed rate may affect the production capability, machining time, tool life and surface roughness [3],[4],[5],[6]. So, a better combination of machining parameters and toolpath strategies may result in good surface roughness. The main focus of this research is to study the influence of machining parameters in pocket milling on surface roughness and also to compare the 3D surface roughness[7] results with 2D surface roughness results to find accuracy of results using two different instruments for better understanding. It is also considered that in pocket milling, obtaining a good surface quality is not so easy because of the penetration of cutting tools into the workpiece before actual cutting starts as the material removal takes place somewhere in the middle of the workpiece. The results of this research might be used to understand forming of surface roughness while machining pockets and also the most effective combination of parameters. The methods which are used in this research were one-way, two-way, helical toolpath strategies.

\section{Design of Experiments}

In this study, the research was performed on a medium carbide steel "C45 (DIN)" having nature of good machinability and tensile strength [8]. A pocket of 40x40x1 mm on a 50x50x50 mm sample was made using an 8 mm carbide end mill cutting tool, the distance of the tool tip from the tool holder is 31mm. "OKUMA GENOS M460-VE" 3-axis milling machine was used throughout the experiments. Machining parameters used in experiments are shown in table 1.

\begin{tabular}{|l|l|}
\hline Toolpath strategies & One-way, Two-way, and Helical (inward) \\
\hline Feed rate $(\mathrm{mm} /$ tooth $)$ & $0.01,0.02,0.03,0.04,0.07$ \\
\hline Cutting speed $(\mathrm{m} / \mathrm{min})$ & $100,150,200,250$ \\
\hline Depth of cut $(\mathrm{mm})$ & 1 \\
\hline Cutting fluid & Air \\
\hline
\end{tabular}

Table 1. List of parameters used in the experiments

\section{Experiments}

A total of 60 samples were machined, 20 each in all the three toolpath strategies. During machining in all three toolpath strategies, feed rate and cutting speeds were varied at constant depth of cut to compare the results. After machining, all the machined samples were measured for surface roughness (Ra) by using "Mitutoyo SJ-500/SV-2100" a 2D surface roughness measuring instrument. For the better illustration of obtained surface, the finest and rougher surfaces obtained in each of the three toolpath strategies were measured for surface roughness ( $\mathrm{Ra}$ ) by using “Taylor Hobson's Talysurfintra" a 3D surface roughness measuring instrument. And "Hirox KH-7700" a digital microscope was used to capture microscopic images of the surface obtained for the better illustration of grain boundaries.

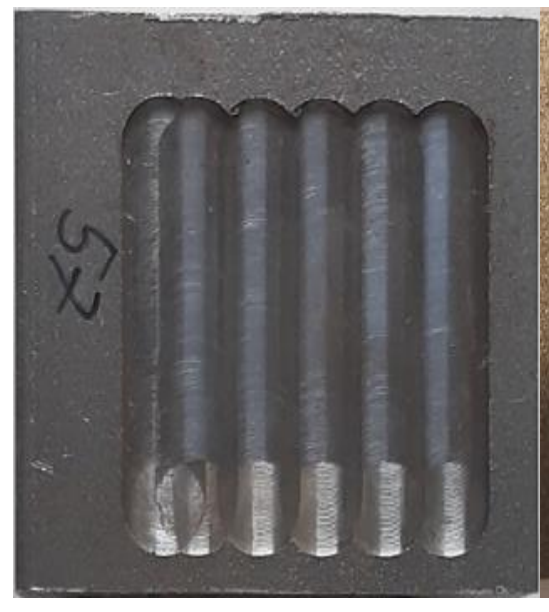

(a) One-way Toolpath

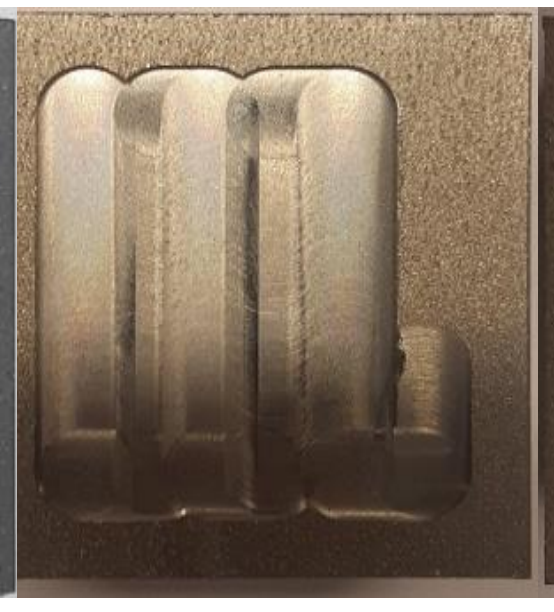

(b) Two-way Toolpath

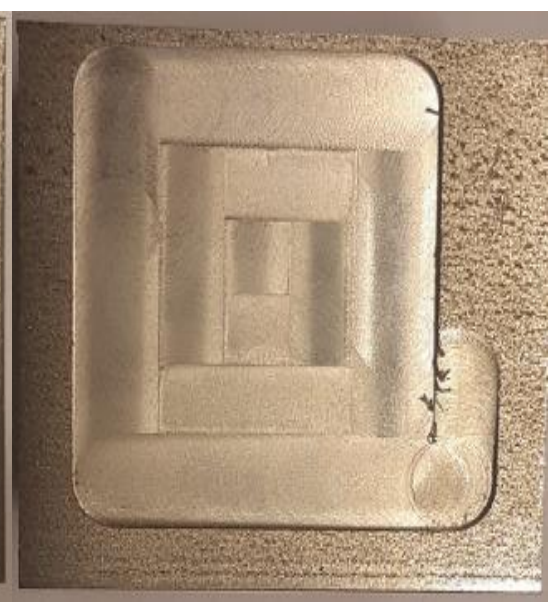

(c) Helical Toolpath

Fig. 1. Illustration of experimented samples.

\section{Results and Analysis of the result}

After conducting all the experiments with different strategies and parameters the results obtained were discussed below. One-way toolpath strategy resulted in better surface roughness for the majority of samples, but there is rubbing of the tool with the work piece at the starting point of tool pass which resulted in poor surface roughness. 
Accordingly, there are more air gaps ( tool moves in air without any cut to move to next point ) in this strategy. After machining, the samples were tested on a $2 \mathrm{D}$ surface roughness instrument for roughness measurement.

\begin{tabular}{|c|c|c|c|c|c|c|}
\hline $\begin{array}{l}\text { Cutting } \\
\text { speed(v) } \\
\mathrm{m} / \mathrm{min}\end{array}$ & $\begin{array}{l}\text { Spindle } \\
\text { Speed(n) } \\
\text { rpm }\end{array}$ & $\begin{array}{c}\text { Depth of cut } \\
\text { (a) } \\
\mathrm{mm}\end{array}$ & $\begin{array}{l}\text { Feed }(\mathrm{f}) \mathrm{mm} / \\
\text { tooth }\end{array}$ & $\begin{array}{c}\text { Surface } \\
\text { roughness } \\
\text { Ra (One-way) } \\
\mu \mathrm{m}\end{array}$ & $\begin{array}{c}\text { Surface } \\
\text { roughness } \\
\text { Ra (Two-way) } \\
\mu \mathrm{m}\end{array}$ & $\begin{array}{c}\text { Surface } \\
\text { roughness } \\
\mathrm{Ra}(\text { Helical }) \\
\mu \mathrm{m}\end{array}$ \\
\hline 100 & 3980 & 1 & 0.01 & 0.77 & 0.95 & 1.3 \\
\hline 100 & 3980 & 1 & 0.02 & 0.59 & 1.01 & 0.85 \\
\hline 100 & 3980 & 1 & 0.03 & 0.67 & 1.15 & 1.26 \\
\hline 100 & 3980 & 1 & 0.04 & 1.16 & 1.33 & 1.47 \\
\hline 100 & 3980 & 1 & 0.07 & 1.25 & 1.61 & 1.99 \\
\hline 150 & 5971 & 1 & 0.01 & 0.58 & 0.94 & 1.1 \\
\hline 150 & 5971 & 1 & 0.02 & 0.51 & 0.44 & 0.46 \\
\hline 150 & 5971 & 1 & 0.03 & 0.49 & 0.89 & 0.89 \\
\hline 150 & 5971 & 1 & 0.04 & 0.86 & 1.18 & 1.01 \\
\hline 150 & 5971 & 1 & 0.07 & 1.35 & 1.85 & 1.6 \\
\hline 200 & 7961 & 1 & 0.01 & 0.57 & 0.64 & 0.33 \\
\hline 200 & 7961 & 1 & 0.02 & 0.44 & 0.86 & 0.52 \\
\hline 200 & 7961 & 1 & 0.03 & 0.64 & 0.95 & 1.12 \\
\hline 200 & 7961 & 1 & 0.04 & 0.83 & 0.96 & 1.04 \\
\hline 200 & 7961 & 1 & 0.07 & 1.37 & 1.66 & 1.79 \\
\hline 250 & 9952 & 1 & 0.01 & 0.42 & 0.51 & 0.37 \\
\hline 250 & 9952 & 1 & 0.02 & 0.36 & 0.68 & 0.72 \\
\hline 250 & 9952 & 1 & 0.03 & 0.35 & 1.01 & 1.19 \\
\hline 250 & 9952 & 1 & 0.04 & 0.91 & 1.26 & 1.21 \\
\hline 250 & 9952 & 1 & 0.07 & 1.33 & 1.29 & 2.23 \\
\hline
\end{tabular}

Table 2. Comparison of average surface roughness (Ra) of all tool path strategies.

\section{Graphical representation of $\mathrm{Ra}$ with feed at respective cutting speeds.}

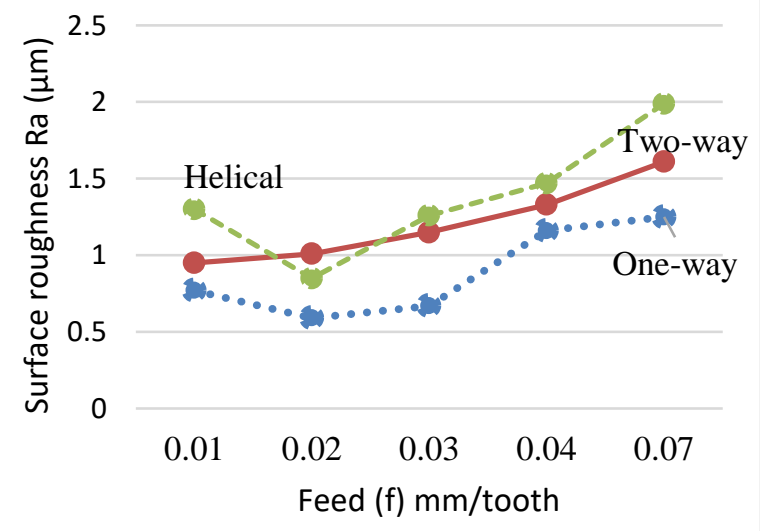

a) Comparison of $\mathrm{Ra}$ at $\mathrm{v}=100 \mathrm{~m} / \mathrm{min}$

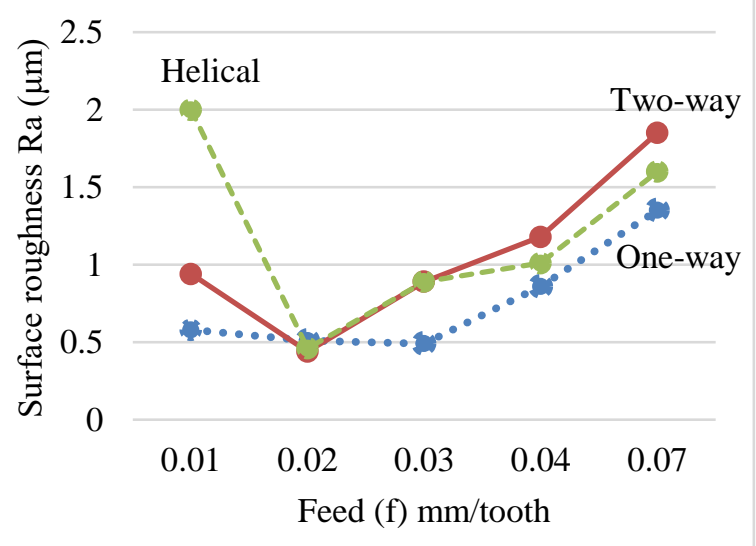

b) Comparison of $\mathrm{Ra}$ at $\mathrm{v}=150 \mathrm{~m} / \mathrm{min}$ 


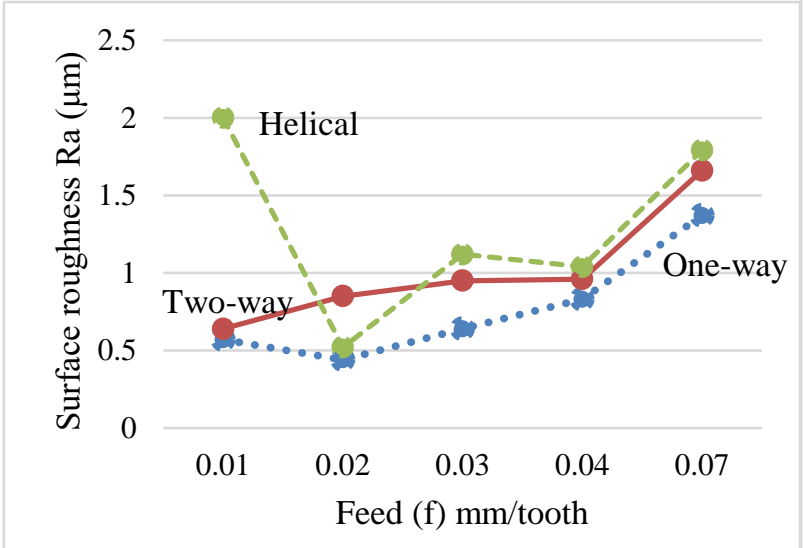

c) Comparison of $\mathrm{Ra}$ at $\mathrm{v}=200 \mathrm{~m} / \mathrm{min}$

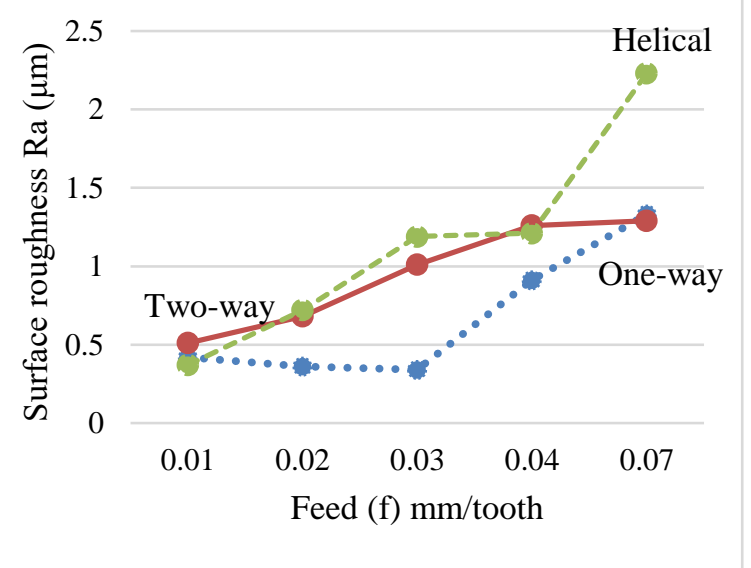

d) Comparison of $\mathrm{Ra}$ at $\mathrm{v}=250 \mathrm{~m} / \mathrm{min}$

Fig. 2. Comparison of Ra of all three toolpath strategies with feed at cutting speed v=100,150,200,250 m/min, respectively

From table 2, it was concluded that at a cutting speed $100 \mathrm{~m} / \mathrm{min}$ with increase in feed (from $0.01-0.07 \mathrm{~mm} /$ tooth) the surface roughness value varied from 0.59 to $1.25 \mu \mathrm{m}$, the better surface obtained at feed $0.02 \mathrm{~mm} /$ tooth $(\mathrm{Ra}=0.59 \mu \mathrm{m})$ and rougher surface obtained at feed $0.07 \mathrm{~mm} /$ tooth $(\mathrm{Ra}=1.25)$. For feed range $0.02-0.03 \mathrm{~mm} /$ tooth, the surface roughness (Ra) is less than $0.70 \mu \mathrm{m}$ indicating better surface. For feed $>0.03 \mathrm{~mm} /$ tooth, the surface roughness (Ra) is greater than $1.0 \mu \mathrm{m}$ indicating rougher surface.

At cutting speed $150 \mathrm{~m} / \mathrm{min}$ with increase in feed (from $0.01-0.07 \mathrm{~mm} /$ tooth) the surface roughness value varied from 0.49 to $1.35 \mu \mathrm{m}$, the better surface obtained at feed $0.03 \mathrm{~mm} /$ tooth $(\mathrm{Ra}=0.49 \mu \mathrm{m})$ and rougher surface obtained at feed $0.07 \mathrm{~mm} /$ tooth $(\mathrm{Ra}=1.35)$. For feed range $0.01-0.03 \mathrm{~mm} /$ tooth, the surface roughness $(\mathrm{Ra})$ is less than $0.60 \mu \mathrm{m}$ indicating better surface. For feed $>0.03 \mathrm{~mm} /$ tooth, the surface roughness $(\mathrm{Ra})$ is greater than $0.8 \mu \mathrm{m}$ indicating rougher surface. At cutting speed $200 \mathrm{~m} / \mathrm{min}$ with increase in feed (from 0.01-0.07 mm/tooth) the surface roughness value varied from 0.44 to $1.37 \mu \mathrm{m}$, the better surface obtained at feed $0.02 \mathrm{~mm} /$ tooth $(\mathrm{Ra}=0.44 \mu \mathrm{m})$ and rougher surface obtained at feed $0.07 \mathrm{~mm} /$ tooth $(\mathrm{Ra}=1.37)$. For feed range $0.01-0.03 \mathrm{~mm} /$ tooth, the surface roughness $(\mathrm{Ra})$ is less than $0.65 \mu \mathrm{m}$ indicating better surface. For feed $>0.03 \mathrm{~mm} /$ tooth, the surface roughness $(\mathrm{Ra})$ is greater than $0.8 \mu \mathrm{m}$ indicating rougher surface. At cutting speed $250 \mathrm{~m} / \mathrm{min}$ with increase in feed (from 0.01-0.07 mm/tooth) the surface roughness value varied from 0.35 to $1.33 \mu \mathrm{m}$, the better surface obtained at feed $0.03 \mathrm{~mm} /$ tooth $(\mathrm{Ra}=0.35 \mu \mathrm{m})$ and rougher surface obtained at feed $0.07 \mathrm{~mm} /$ tooth $(\mathrm{Ra}=1.33)$. For feed range $0.01-0.03 \mathrm{~mm} /$ tooth, the surface roughness $(\mathrm{Ra})$ is less than $0.50 \mu \mathrm{m}$ indicating better surface. For feed $>0.03 \mathrm{~mm} /$ tooth, the surface roughness $(\mathrm{Ra})$ is greater than $0.9 \mu \mathrm{m}$ indicating rougher surface. Better surface roughness (Ra) $0.35-0.42 \mu \mathrm{m}$ was obtained using a depth of cut of $1 \mathrm{~mm}$, a cutting speed of $250 \mathrm{~m} / \mathrm{min}$ and a feed of 0.01 to $0.03 \mathrm{~mm} /$ tooth. Rougher surface (with $\mathrm{Ra}>1.3 \mu \mathrm{m}$ ) is obtained at feed $0.07 \mathrm{~mm} /$ tooth for cutting speed $100-250 \mathrm{~m} / \mathrm{min}$.

In pocket milling of $\mathrm{C} 45$ using one-way toolpath strategy, the most influential technological parameter on the surface roughness $(\mathrm{Ra})$ is the feed. Better and smooth surface is obtained at low feeds. At cutting speed $100 \mathrm{~m} / \mathrm{min}$ with increase in feed (from 0.01-0.07 mm/tooth) the surface roughness value varied from 0.95 to $1.61 \mu \mathrm{m}$, the better surface obtained at feed $0.01 \mathrm{~mm} /$ tooth $(\mathrm{Ra}=0.95 \mu \mathrm{m})$ and rougher surface obtained at feed $0.07 \mathrm{~mm} /$ tooth $(\mathrm{Ra}=1.61)$. For feed 0.01 $\mathrm{mm} /$ tooth, the surface roughness $(\mathrm{Ra})$ is $0.95 \mu \mathrm{m}$ which is almost $10 . \mu \mathrm{m}$ indicating rougher surface. For feed $>0.02$ $\mathrm{mm} /$ tooth, the surface roughness $(\mathrm{Ra})$ is greater than $1.0 \mu \mathrm{m}$ indicating an even rougher surface. There is a noticeable increase of roughness $(\mathrm{Ra})$ with increase in feed at same cutting speed.

At cutting speed $150 \mathrm{~m} / \mathrm{min}$ with increase in feed (from $0.01-0.07 \mathrm{~mm} /$ tooth) the surface roughness value varied from 0.94 to $1.85 \mu \mathrm{m}$, the better surface obtained at feed $0.02 \mathrm{~mm} /$ tooth $(\mathrm{Ra}=0.44 \mu \mathrm{m})$ and rougher surface obtained at feed $0.07 \mathrm{~mm} /$ tooth $(\mathrm{Ra}=1.87)$. For feed range $0.02 \mathrm{~mm} /$ tooth, the surface roughness $(\mathrm{Ra})$ is $0.44 \mu \mathrm{m}$ indicating better surface. For feed 0.01 and greater than $0.03 \mathrm{~mm} /$ tooth, the surface roughness $(\mathrm{Ra})$ is greater than $0.9 \mu \mathrm{m}$ indicating rougher surface. There is a noticeable increase of roughness $(\mathrm{Ra})$ with increase in feed at same cutting speed.

At cutting speed $200 \mathrm{~m} / \mathrm{min}$ with increase in feed (from $0.01-0.07 \mathrm{~mm} /$ tooth) the surface roughness value varied from 0.64 to $1.66 \mu \mathrm{m}$, the better surface obtained at feed $0.01 \mathrm{~mm} /$ tooth $(\mathrm{Ra}=0.64 \mu \mathrm{m})$ and rougher surface obtained at feed $0.07 \mathrm{~mm} /$ tooth $(\mathrm{Ra}=1.66)$. For feed range $0.01 \mathrm{~mm} /$ tooth, the surface roughness $(\mathrm{Ra}) 0.65 \mu \mathrm{m}$ indicating better surface. For feed $>0.02 \mathrm{~mm} /$ tooth, the surface roughness $(\mathrm{Ra})$ is greater than $0.8 \mu \mathrm{m}$ indicating rougher surface. There is a noticeable increase of roughness $(\mathrm{Ra})$ with increase in feed at same cutting speed. At cutting speed $250 \mathrm{~m} / \mathrm{min}$ with increase in feed (from $0.01-0.07 \mathrm{~mm} /$ tooth) the surface roughness value varied from 0.51 to $1.29 \mu \mathrm{m}$, the better surface obtained at feed $0.01 \mathrm{~mm} /$ tooth $(\mathrm{Ra}=0.51 \mu \mathrm{m})$ and rougher surface obtained at feed $0.07 \mathrm{~mm} /$ tooth $(\mathrm{Ra}=1.29)$. For feed range $0.01-0.02 \mathrm{~mm} /$ tooth, the surface roughness $(\mathrm{Ra})$ is $0.51-0.68 \mu \mathrm{m}$ indicating better surface. 
For feed $>0.03 \mathrm{~mm} /$ tooth, the surface roughness $(\mathrm{Ra})$ is greater than $1 \mu \mathrm{m}$ indicating rougher surface. There is a noticeable increase of roughness (Ra) with increase in feed at same speed. Better surface roughness (Ra) $0.44 \mu \mathrm{m}$ was obtained using a depth of cut of $1 \mathrm{~mm}$, a cutting speed of $150 \mathrm{~m} / \mathrm{min}$ and a feed of $0.02 \mathrm{~mm} /$ tooth. Rougher surface (with $\mathrm{Ra}=1.85 \mu \mathrm{m}$ ) is obtained at feed $0.07 \mathrm{~mm} /$ tooth for cutting speed $150 \mathrm{~m} / \mathrm{min}$. For cutting speed 100-250 m/min, with increase in feed the surface roughness $(\mathrm{Ra})$ is also increasing and surface is becoming rougher. At a cutting speed of 100 $\mathrm{m} / \mathrm{min}$, with feed $0.01-0.07$, the $\mathrm{Ra}$ is $\geq 1$ indicating that in two-way at low cutting speed and low feeds a rougher surface is obtained.

In pocket milling of C45 using two-way toolpath strategy, the most influential technological parameter on the surface roughness $(\mathrm{Ra})$ is the feed. Better and smooth surface will be obtained at low feeds and cutting speed greater than 150 $\mathrm{m} / \mathrm{min}$. At cutting speed $100 \mathrm{~m} / \mathrm{min}$ with increase in feed (from 0.01-0.07 mm/tooth) the surface roughness value varied from 0.85 to $1.99 \mu \mathrm{m}$, the better surface obtained at feed $0.02 \mathrm{~mm} /$ tooth $(\mathrm{Ra}=0.85 \mu \mathrm{m})$ and rougher surface obtained at feed $0.07 \mathrm{~mm} /$ tooth $(\mathrm{Ra}=1.99)$. For feed $0.02 \mathrm{~mm} /$ tooth, the surface roughness $(\mathrm{Ra})$ is $0.85 \mu \mathrm{m}$ which is almost $1.0 \mu \mathrm{m}$ indicating rougher surface. For feed 0.01 and $>0.02 \mathrm{~mm} /$ tooth, the surface roughness $(\mathrm{Ra})$ is greater than $1.0 \mu \mathrm{m}$ indicating an even rougher surface. There is a noticeable increase of roughness ( $\mathrm{Ra}$ ) with increase in feed at same cutting speed.

At cutting speed $150 \mathrm{~m} / \mathrm{min}$ with increase in feed (from $0.01-0.07 \mathrm{~mm} /$ tooth) the surface roughness value varied from 0.46 to $1.6 \mu \mathrm{m}$, the better surface obtained at feed $0.02 \mathrm{~mm} /$ tooth $(\mathrm{Ra}=0.46 \mu \mathrm{m})$ and rougher surface obtained at feed 0.07 $\mathrm{mm} /$ tooth $(\mathrm{Ra}=1.6)$. For feed range $0.02 \mathrm{~mm} /$ tooth, the surface roughness $(\mathrm{Ra})$ is $0.44 \mu \mathrm{m}$ indicating better surface. For feed 0.01 and $>0.02 \mathrm{~mm} /$ tooth, the surface roughness $(\mathrm{Ra})$ is greater than $0.9 \mu \mathrm{m}$ indicating rougher surface. There is a noticeable increase of roughness $(\mathrm{Ra})$ with increase in feed at same cutting speed.

At cutting speed $200 \mathrm{~m} / \mathrm{min}$ with increase in feed (from $0.01-0.07 \mathrm{~mm} /$ tooth) the surface roughness value varied from 0.33 to $1.79 \mu \mathrm{m}$, the better surface obtained at feed $0.01 \mathrm{~mm} /$ tooth $(\mathrm{Ra}=0.33 \mu \mathrm{m})$ and rougher surface obtained at feed $0.07 \mathrm{~mm} /$ tooth $(\mathrm{Ra}=1.79)$. For feed range $0.01-0.02 \mathrm{~mm} /$ tooth, the surface roughness ( $\mathrm{Ra})$ 0.33-0.52 $\mu \mathrm{m}$ indicating better surface. For feed $>0.02 \mathrm{~mm} /$ tooth, the surface roughness $(\mathrm{Ra})$ is greater than $1 \mu \mathrm{m}$ indicating rougher surface. There is a noticeable increase of roughness $(\mathrm{Ra})$ with increase in feed at same cutting speed.

At cutting speed $250 \mathrm{~m} / \mathrm{min}$ with increase in feed (from $0.01-0.07 \mathrm{~mm} /$ tooth) the surface roughness value varied from 0.37 to $2.23 \mu \mathrm{m}$, the better surface obtained at feed $0.01 \mathrm{~mm} /$ tooth $(\mathrm{Ra}=0.37 \mu \mathrm{m})$ and rougher surface obtained at feed $0.07 \mathrm{~mm} /$ tooth $(\mathrm{Ra}=2.23)$. For feed range $0.01-0.02 \mathrm{~mm} /$ tooth, the surface roughness $(\mathrm{Ra})$ is $0.37-0.72 \mu \mathrm{m}$ indicating better surface. For feed $>0.02 \mathrm{~mm} /$ tooth, the surface roughness $(\mathrm{Ra})$ is greater than $1 \mu \mathrm{m}$ indicating rougher surface. There is a noticeable increase of roughness $(\mathrm{Ra})$ with increase in feed at same speed.

Better surface roughness (Ra) $0.33 \mu \mathrm{m}$ was obtained using a depth of cut of $1 \mathrm{~mm}$, a cutting speed of $200 \mathrm{~m} / \mathrm{min}$ and a feed of $0.01 \mathrm{~mm} /$ tooth. Rougher surface (with $\mathrm{Ra}=2.23 \mu \mathrm{m}$ ) is obtained at feed $0.07 \mathrm{~mm} /$ tooth for cutting speed 250 $\mathrm{m} / \mathrm{min}$. For cutting speed 100-250 $\mathrm{m} / \mathrm{min}$, with increase in feed the surface roughness (Ra) is also increasing and surface is becoming rougher. At a cutting speed of $100 \mathrm{~m} / \mathrm{min}$, with feed $0.01-0.07$, the Ra is $\geq 1$ indicating that in helical toolpath strategy at low cutting speed results in rougher surface. The above results indicate low speeds and high feed (irrespective of cutting speed) are not suitable for obtaining better surface roughness in helical toolpath strategy.

In pocket milling of $\mathrm{C} 45$ using helical toolpath strategy, the most influential technological parameter on the surface roughness $(\mathrm{Ra})$ is the feed. Better and smooth surface can be obtained at low feeds (0.01-0.02) and at cutting speed $\geq 150$ $\mathrm{m} / \mathrm{min}$.

\section{D illustration of samples with better surface roughness and Poor surface roughness}

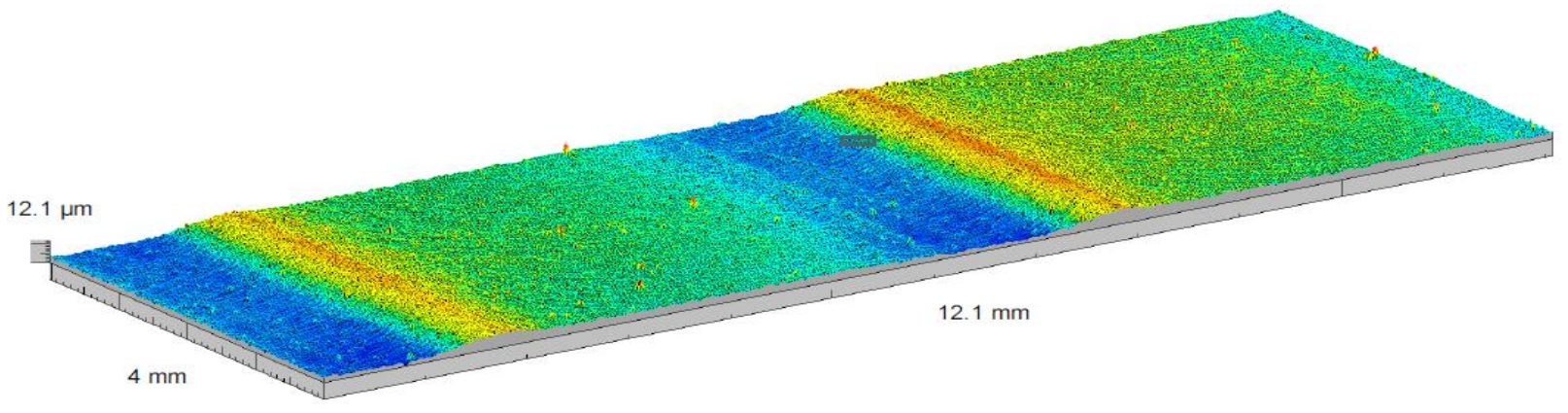

Fig. 3. 3D illustration of one-way toolpath strategy sample with better surface roughness at $\mathrm{V}=250 \mathrm{~m} / \mathrm{min}, \mathrm{Feed}=0.02$, $\mathrm{Ra}=0.36 \mu \mathrm{m}, \mathrm{Sa}=0.29 \mu \mathrm{m}, \mathrm{Sq}=0.37 \mu \mathrm{m}$. The width of the sample is $12.1 \mathrm{~mm}$ and a length of the sample is $4 \mathrm{~mm}$.

In the above figure 3 , it is noticed that even though the surface obtained is smoother, there are noticeable peaks at the points where the toolpath overlaps. There is also a noticeable step which results in waviness. In very precise parts for better results it is better to study waviness also. 


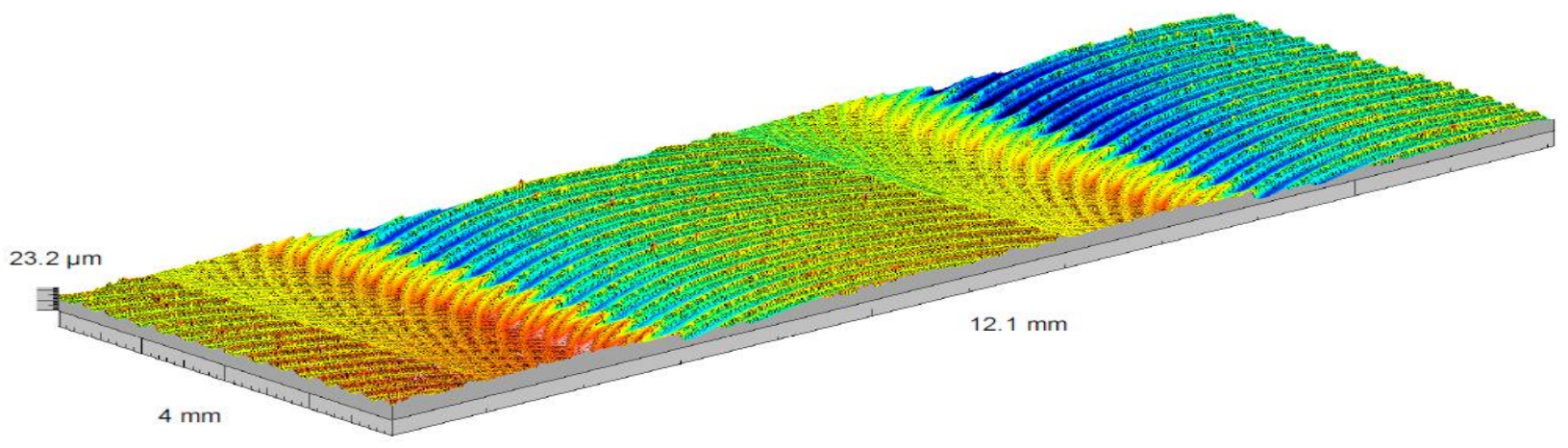

Fig. 4. 3D illustration of one-way toolpath strategy sample with better surface roughness at V=250m $/ \mathrm{min}, \mathrm{Feed}=0.07$, $\mathrm{Ra}=1.33 \mu \mathrm{m}, \mathrm{Sa}=1.25 \mu \mathrm{m}, \mathrm{Sq}=1.6 \mu \mathrm{m}$. The width of the sample is $12.1 \mathrm{~mm}$ and a length of the sample is $4 \mathrm{~mm}$.

In the above figure 4 , it is noticed that there are peaks throughout the surface which resulted in poor surface. When compared to figure 3, steps in this sample are lesser but scratches by tool occur on the entire surface. In very precise parts, for better results it is necessary to study waviness also.

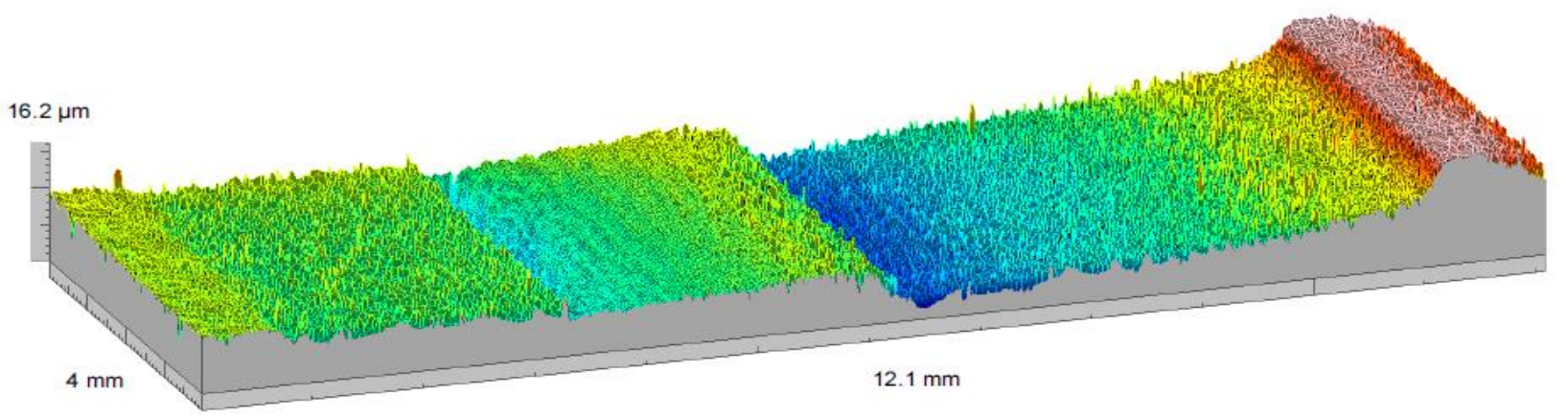

Fig. 5. 3D illustration of Two-way toolpath strategy sample with better surface roughness at $\mathrm{V}=150 \mathrm{~m} / \mathrm{min}, \mathrm{Feed}=0.02$, $\mathrm{Ra}=0.44 \mu \mathrm{m}, \mathrm{Sa}=0.33 \mu \mathrm{m}, \mathrm{Sq}=0.43 \mu \mathrm{m}$. The width of the sample is $12.1 \mathrm{~mm}$ and a length of the sample is $4 \mathrm{~mm}$.

In the above figure 5 , it is noticed that even though the surface obtained is smoother, there are noticeable peaks at the points where the toolpath overlaps. The surface obtained here is in $\mathrm{V}$-shape. There are also big steps which result in waviness. When compared to a better surface sample in one-way strategy (figure 3), in this sample the steps are bigger due to larger overlap of toolpaths. In very precise parts for better results it is better to study waviness also.

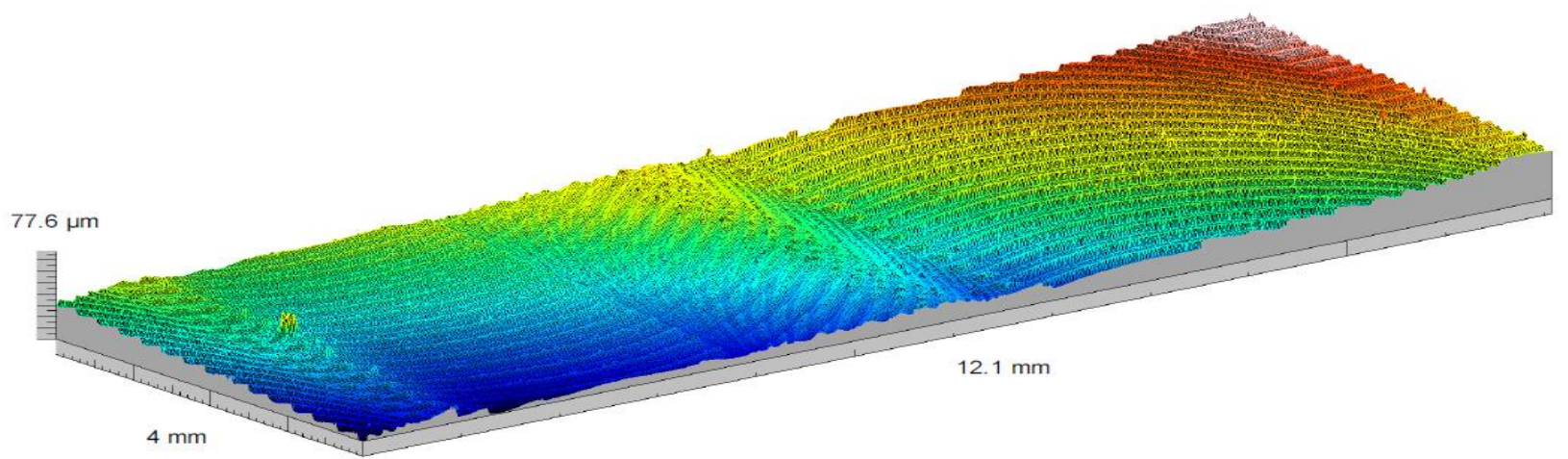

Fig. 6. 3D illustration of Two-way toolpath strategy sample with better surface roughness at $\mathrm{V}=150 \mathrm{~m} / \mathrm{min}, \mathrm{Feed}=0.07$, $\mathrm{Ra}=1.85 \mu \mathrm{m}, \mathrm{Sa}=1.32 \mu \mathrm{m}, \mathrm{Sq}=1.62 \mu \mathrm{m}$. The width of the sample is $12.1 \mathrm{~mm}$ and a length of the sample is $4 \mathrm{~mm}$.

In the above figure 6 , it is noticed that there are peaks throughout the surface which resulted in poor surface. The surface obtained here is in curved shape. When compared to figure 5, steps in this sample are lesser but scratches by tool occur on the entire surface. In very precise parts, for better results it is necessary to study waviness also. 


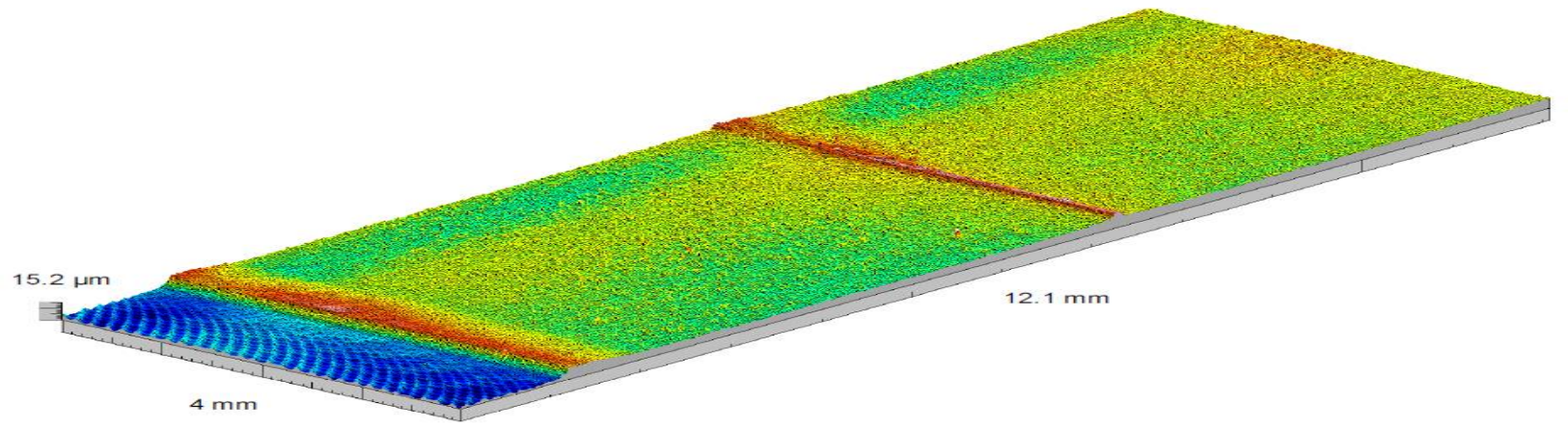

Fig. 7. 3D illustration of Helical toolpath strategy sample with better surface roughness at $\mathrm{V}=200 \mathrm{~m} / \mathrm{min}$, Feed=0.01,

$\mathrm{Ra}=0.33 \mu \mathrm{m}, \mathrm{Sa}=0.27 \mu \mathrm{m}, \mathrm{Sq}=0.38 \mu \mathrm{m}$. The width of the sample is $12.1 \mathrm{~mm}$ and a length of the sample is $4 \mathrm{~mm}$.

In the above figure 7, it is noticed that even though the surface obtained is smoother, there are minor peaks at the points where the toolpath overlaps. The surface obtained here is almost flat with small steps. When compared to a better surface sample in one-way strategy (figure 3) and two-way strategy (figure 4), in this sample the steps are very small which results in small waves on the surface. In very precise parts, for better results it is necessary to study waviness also.

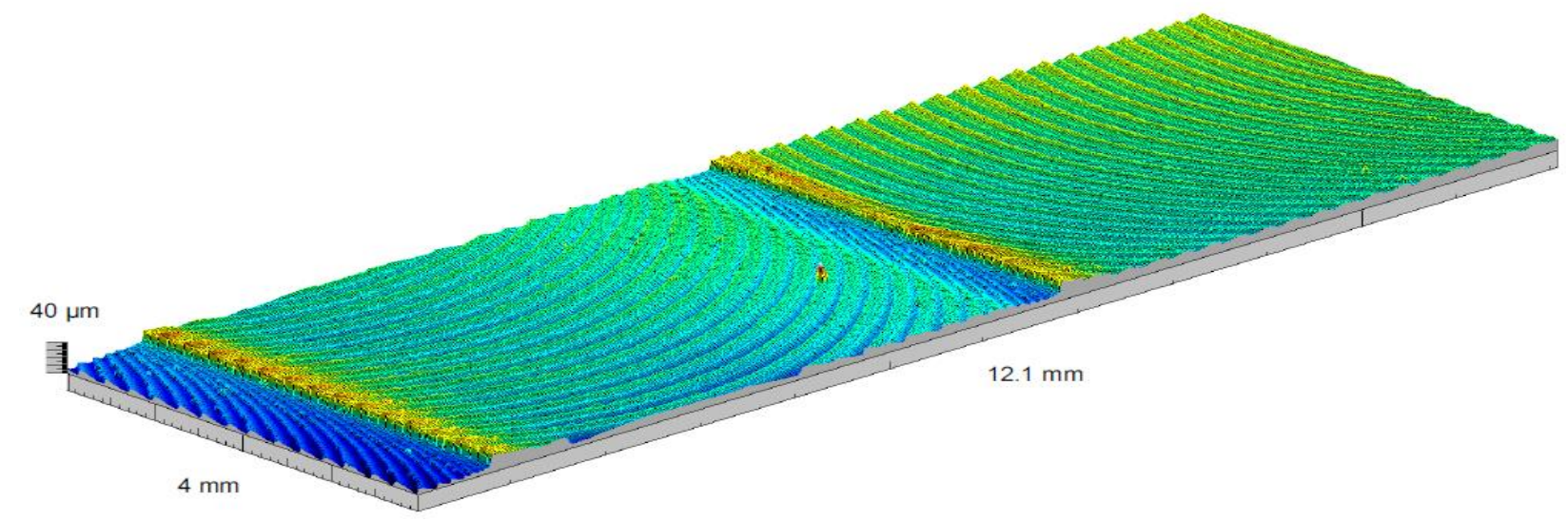

Fig. 8. 3D illustration of Helical toolpath strategy sample with better surface roughness at $\mathrm{V}=250 \mathrm{~m} / \mathrm{min}$, Feed=0.07, $\mathrm{Ra}=2.23 \mu \mathrm{m}, \mathrm{Sa}=1.81 \mu \mathrm{m}, \mathrm{Sq}=2.23 \mu \mathrm{m}$. The width of the sample is $12.1 \mathrm{~mm}$ and a length of the sample is $4 \mathrm{~mm}$.

In the above figure 8 , it is noticed that there are peaks throughout the surface which resulted in poor surface. The surface obtained here is flat with small hills. When compared to figure 7, steps are little bigger and also scratches by tool are noticeable throughout the surface. In very precise parts, for better results it is necessary to study waviness also.

\section{Conclusion}

Surface roughness in pocket milling is affected by technological parameters such as cutting speed, depth of cut, feed as well as toolpath strategy. Toolpath strategy affects not only a surface roughness but also a machining time. In pocket milling of C45 using one-way toolpath strategy, the most influential technological parameter on the surface roughness $(\mathrm{Ra})$ is feed rate and while in two-way and helical toolpath strategy, the most influential technological parameter on the surface roughness $(\mathrm{Ra})$ are feed and cutting speed. In pocket milling of $\mathrm{C} 45$ the most influential technological parameters on the surface roughness ( Ra) are feed and cutting speed. Lower feeds and higher cutting speeds give better results in pocket milling of C45. At low cutting speeds $(100-200 \mathrm{~m} / \mathrm{min})$ a formation of burr was noticed due to low cutting forces. Overall, helical toolpath strategy is far better than one-way and two-way strategies because of its machining time, productivity, and quality of surface. Further research can be done on technological assurance of surface waviness (to obtain a flat and smooth surface without waviness). Also, by searching new toolpath strategies and varying depth of cut. Research could be also performed on studying the influence of up-milling and down-milling on surface roughness.

\section{References}

[1] A.Etyemez, Niken Turkey, Kucukyali Is Merkezi Maltepe. (2015). “Optimization of Effects of Pocket Toolpath Strategies and Cutting Parameters on Surface Quality”, 5th International Science Congress \& Exhibition APMAS2015, Lykia, Oludeniz, 34852 Istanbul, Turkey, DOI: 10.12693/APhysPolA.129.886. 
[2] Hamid Ramazani Sales, Hossein Amirabadi, Hossein Nouri Hosseinabadi and Mohammad Reza Bagheri. (2016) "Experimental Study of Tool Path Strategies for Three and Five axes Milling along with Feed Rate Optimization", Indian Journal of Science and Technology, Vol 9(43), DOI:10.17485/ijst/2016/v9i43/104966.

[3] P.E.Romero, R. Dorado, F.A. Diaz, E.M. Rubio. (2013). "Influence of Pocket Geometry and Tool Path Strategy in Pocket Milling of UNSA 96063 Alloy", Procedia engineering, volume 63, pp.523-531.

[4] Rusdi Mat Song, Safian Sharif, Ahmad Yasir Md Said, Mohd Tanwyn Mohd Khushairi. (2014) "Effect of Tool Path Strategies in Pocket Milling of Aluminium Epoxy", DOI: 10.4028/www.scientific.net/AMR.903.15.

[5] Y T Wibowo, S Y Baskoro and V A T Manurung. (2018) "Toolpath Strategy and Optimum Combination of Machining Parameter during Pocket Mill Process of Plastic Mold Steels Material”, IOP conference series: Materials Science and engineering, Volume 306

[6] Nexhat Qehaja, Ilir Doci, Mirlind Bruci, Fitore Abdullahu, Kaltrine Jakupi \& Fatlume Zhujani. (2016). Mathematical Modelling of Surface Roughness Through Machining Parameters and Machining Time During the Dry Milling Process, Preceedings of the 27th DAAAM International Symposium, pp.0187-0194, B. Katalinic (Ed.), Published by DAAAM International, ISBN 978-3-902734-08-2, ISSN 1726-9679, Vienna, Austria, DOI: 10.2507/27th.daaam.preceedings.028

[7] Andris Logins, Toms Torims. (2014). The Influence of High-Speed Milling Strategies on 3D Surface Roughness Parameter, Proceedings of the 25th DAAAM International Symposium, https://www.sciencedirect.com Accessed: 2019.03.15

[8] Https://www.materialgrades.com, C45 Medium Carbon Steel grade properties, Accessed: 2019-05-20 